SOUTHERN

\title{
The French do it better. The distributive effect of introducing French family fiscal policies in Italy.
}

\author{
Paolo Brunori \\ Maria Luisa Maitino \\ Letizia Ravagli \\ Nicola Sciclone
}

SERIES Working PAPERS N. 04/2019

SERIES sono pubblicati a cura del Dipartimento di Scienze economiche e metodi matematici dell'Università degli Studi di Bari "Aldo Moro". I lavori riflettono esclusivamente le opinioni degli autori e non impegnano la responsabilità del Dipartimento. SERIES vogliono promuovere la circolazione di studi ancora preliminari e incompleti, per suscitare commenti critici e suggerimenti. Si richiede di tener conto della natura provvisoria dei lavori per eventuali citazioni o per ogni altro uso.
SERIES are published under the auspices of the Department of Economics of the University of Bari. Any opinions expressed here are those of the authors and not those of the Department. Often SERIES divulge preliminary or incomplete work, circulated to favor discussion and comment. Citation and use of these paper should consider their provisional character. 


\title{
The French do it better.
}

\section{The distributive effect of introducing French family fiscal policies in Italy.*}

\section{Paolo Brunori}

Università degli Studi di Firenze, Firenze, Italia. paolo.brunori@unifi.it

\section{Maria Luisa Maitino}

Istituto Regionale Programmazione Economica della Toscana, Firenze, Italia. marialuisa.maitino@irpet.it

\section{Letizia Ravagli}

Istituto Regionale Programmazione Economica della Toscana, Firenze, Italia. letizia.ravagli@irpet.it

\section{Nicola Sciclone}

Istituto Regionale Programmazione Economica della Toscana, Firenze, Italia. nicola.sciclone@irpet.it

\begin{abstract}
:
Italy has one of the lowest fertility rates in the world. A solution, often advocated to incentivize fertility, could be to reform the Italian fiscal system, taking inspiration from the French fiscal family treatment. This would imply introducing the quotient system, where taxation is not on an individual basis, as in Italy, but is applied to the family as a whole, and the cash benefits provided to families in France. The purpose of ourpaper is to assess the distributive effects of such a fiscal reform. We estimate these effects using MicroReg, a static microsimulation model that is able to predict the first-order effects of fiscal reforms. We show that a shift to the French income tax system would lead to decreased income inequality and a substantial tax reduction for households with three children, especially those with medium-high income. The new income tax would result in a substantial disincentive to female labor supply, albeit mitigated by greater progressivity in favor of low-income groups with children.
\end{abstract}

KEYWORDS: MICROSIMULATION, FAMILY QUOTIENT, FERTILITY, INEQUALITY.

JEL classification: $\mathrm{H} 24, \mathrm{~J} 13, \mathrm{D} 63$, J22

\footnotetext{
${ }^{*}$ We are grateful to all Espanet 2018 participants for useful comments on the paper. All remaining errors are our responsibility.
} 


\section{INTRODUCTION}

The fertility rate in Italy is low at 1.34, which is lower than the replacement fertility level of 2.1 children per woman. One of the possible solutions to stimulate fertility is a fiscal reform that could lighten the tax burden on larger households and increase cash subsidies to families with children. In this paper, we estimate the distributive effects of a reform of the Italian tax and benefit system inspired by the French model. In fact, France has a high fertility rate and a tax-benefit system that tends to favor the choice to have children.

Our hypothetical reform would introduce the French "family quotient" and replace the Italian cash subsidies to households with children with those in force in France. We analyze the redistributive effects by distinguishing households by deciles of equivalent household income and number of children and by calculating the classic indicators on income distribution inequality. We also consider the possible effects on labor market participation by estimating the change in women's effective marginal tax rates after the hypothetical adoption of the French income tax. The simulation of the new tax-benefit system is made through MicroReg, a static microsimulation model built on the Italian subsample of the European Survey on Income and Living Conditions (EU-SILC).

Our analysis confirms that, indeed, an income tax inspired by the French system, based on the socalled family quotient, would reduce the tax burden and substantially increase cash transfers for families with children. However, the most advantaged by such a reform would be families with three or more children. Because, in Italy, the average number of children per woman does not reach two, one may question whether this system of incentives would have the same efficacy in Italy, where the number of couples considering the possibility of having a third child is limited. Our analysis confirms that the family quotient tends to discourage the labor supply of family members earning relatively lower gross wages. This may be a key side effect of such a fiscal reform in the case of Italy, where a low fertility rate goes hand in hand with limited labor force participation, especially among women. To assess the order of magnitude of this distortion for nonworking women, we simulate the effect of the reform in terms of the tax burden. We assume that nonworking women could enter the labor market with a part-time job, and we simulate the different tax burdens under the two fiscal regimes. The estimated increase in the average tax rate is substantial. However, due to the stronger progressivity of the French income tax rate, this effect is weaker for families with lower incomes. 
Finally, the analysis considers that, in France, the family quotient is coupled with a generous system of subsidies. A more generous system of cash transfer to large families may be a second important element explaining the higher fertility rate. We therefore extend our analysis considering the possibility of replacing the Italian system of family cash transfers with the French system of subsidies. The analysis highlights that adopting the French system of transfers would not only favor larger families but also make the Italian social welfare system more progressive.

The paper is organized as follows: the second section reviews the main literature on the effects of fiscal policies on fertility, focusing on the French case. The third describes the fiscal treatment of household and the social transfers for households with children in France and Italy. The fourth analyses the distributive impact of shifting from the Italian to the French tax-benefit system and the effects on the effective marginal tax rates for women. Finally, we make some concluding remarks.

\section{FISCAL POLICIES AND FERTILITY}

Many studies have investigated the effects of public policies on fertility choices, as shown by several reviews: Sleebos (2003), Gauthier (2007) and Thévenon and Gauthier (2011). Studies generally divide policies in two categories: direct, such as fiscal policies (social transfers or tax discounts) and facilitated loans, and indirect, from care services to parental leave and flexible work schedules. The effect of such policies on fertility is measured by a variety of indicators, such as the total fertility rate, the timing of child bearing or the probability of having children distinguished by birth order and mother's age. The results are not always conclusive and unambiguous, but in general, a positive impact of policies on fertility is observed, even if it is rather weak. Furthermore, a number of contributions suggest that policies have more effect on the time when women decide to have children than on the total number of children.

A few of studies focus on the effect of the French tax and benefit on fertility and show a positive impact of implemented policies on the probability of having a higher number of children (Thévenon, 2009). The only paper that explicitly focuses on the effects of the family quotient on fertility is Landais (2003). The analysis is based on tax returns data available since 1915. The causal effect of policies on fertility is estimated by applying the difference-in-difference methodology to two legislative changes that occurred in the 1980s. The family quotient was introduced in 1945. It was, initially, an equivalence scale to be applied to household taxable income, which took into account the tax burden due to children, especially starting from the fifth child. In 1980, the quotient 
was reformed and strengthened starting from the third child. However, in 1981, a limit to its effects was introduced by setting a ceiling to the tax rebate obtainable.

Landais evaluated the effect of the two legislative changes, starting from the ceiling introduced in 1981. He compared the fertility of very high-income households, for which the ceiling was applied, to that of slightly lower-income households, untouched by the reform. The difference in the average number of children before and after the reform and between the two groups was positive, even if limited, which would seem to confirm that the reduction of the rebate connected to the family quotient reduced fertility.

To evaluate the effects of the 1980 introduction of a favorable quotient starting from the third child, Landais compared the share of households with two children to that with three children in the years before and after the reform. Considering the five years before and after 1980, the estimated effect of the tax incentives appeared positive but weak and tended to manifest some years after the reform.

Similarly, Ekert (1986) evaluated various forms of household support, summarized in a policy index based on data from the late 1970s. Ekert estimated a regression model to exploit the variability of policies between several European countries, including France, to explain differences in fertility rates. Social subsidies appear to have a positive but weak impact on fertility. The overall effect of the French tax system on fertility was estimated at 0.2 children per woman.

Breton and Prioux (2005) focused on French third-child policies. Over the years, these policies, including the family quotient, have been subject to numerous and inconsistent reforms. At the time the authors wrote, there were three policies favoring three-child families: household allowances, the subsidy for low-income households with three children and the family quotient. To evaluate these policies, Breton and Prioux took advantage of the changes in regulations over time by comparing the frequency of households going from first to second child to that of households going from second to third child beginning in the 1970s. The authors concluded that it was very likely that the policies had a positive and significant effect on the probability of going from the second to the third child.

Piketty (2005) used the extension of the Allocation Parentale d'Education (APE) ${ }^{\mathrm{i}}$ of 1994 as a natural experiment to estimate the elasticity in female labor market participation and fertility. The 1990s reform provided the opportunity to request the benefit at the birth of the second child, instead of the third one, as was previously done. The study, conducted on sample data, shows that the reform contributed to widening the gap between mothers of two children and mothers of three.

Later, Laroque and Salaniè (2013) followed a different approach. Their work estimated a discrete model of the decision to have children and participate in the labor market based on data from the 
French Labour Force Survey. According to their study, financial incentives had a positive and significant impact on the decision to have children, especially a third child.

\section{FISCAL FAMILY POLICIES IN ITALY AND FRANCE}

In comparing French and Italian family policies, we limit our analysis to income tax and cash benefits. The analysis therefore ignores a less important aspect of family policies: the opportunity to have access to child-care services.

\subsection{Income tax}

The main income tax distinction between the two countries is the taxable unit. Italy applies the personal income tax to individuals (IRPEF). In France, the tax unit for income taxation is neither individual nor household based. Instead, it concerns a subgroup of the household that consists of one taxpayer plus the spouse, whether they are married or have signed a contract of civil partnership, and all dependent children/adults. Dependent children are children under 18 (automatically); children strictly under 21 (if they agree to be declared with their parents); children strictly under 25 who are students (if they agree to be declared with their parents); and disabled children (automatically whatever their age); other adults can also be dependent if they are disabled. To take into account the family size, the French taxation system gives a weight to each family member and adds them together to compute the family ratio so called "quotient familial" (QF) (Table 1).

Table 1: The French family quotient

\begin{tabular}{lc}
\hline Household type and children & QF \\
\hline Married or cohabiting couples & 2 \\
Single & 1 \\
Single parent with at least one dependent child & 1.5 \\
Widow/er/s with at least one dependent child & 2 \\
First child & 0.5 \\
Second child & 0.5 \\
Every child after the second & 1 \\
\hline
\end{tabular}

The amount that is submitted to the tax schedule is the net taxable income ${ }^{\dagger}$ divided by the QF. The tax amount obtained is then multiplied by the QF to yield the total tax for the tax unit. Let us call it "normal tax liability". However, a ceiling is introduced to limit the benefits from the weight of

† There are deductions (“abattement”) for certain categories of income. 
dependent children. A "new tax" needs to be recalculated with a QF of 1 for single and 2 for couples. Then, from the new tax, the following ceiling (Table 2) is subtracted.

Table 2: "QF" ceiling for family type and "part"

\begin{tabular}{ll}
\hline Family type and "part" & Ceiling \\
\hline The two first 0.5 for lone parent & 3,562 euro \\
Each 0.5 after the second for lone parent & 1,510 euro \\
Each 0.5 & 1,510 euro \\
\hline
\end{tabular}

Let us call Imax the difference between the new tax calculated and the ceilings. The tax to pay is the maximum between the normal tax liability and Imax ${ }^{\ddagger}$. This complex calculation mechanism should guarantee horizontal equity: for the same income, a household with more dependents, and consequently a higher quotient, is applied a lower average income tax rate than a household with fewer dependents.

The Italian tax system achieves horizontal equity through a system of tax credits for household dependents. Each taxable individual has a theoretical amount of tax credit for his or her dependent spouse, children and other household dependents. The amount is distinguished by the age and number of children.

Vertical equity is achieved in both systems through increasing tax rates for income brackets (Table 3). The growth profile of tax rates by brackets is more pronounced in the French system than in Italy.

Table 3: Income tax features in Italy and France

\begin{tabular}{|c|c|c|}
\hline & Italy & France \\
\hline Taxation unit & Individual & "Fiscal household" \\
\hline Taxable base & Total individual income (y) & $\begin{array}{l}\text { Total household income (y) divided by } \\
\text { number of "parts" (q= "family quotient") }\end{array}$ \\
\hline Legal rates & $\begin{array}{l}23 \% \text { up to } 15,000 \text { euros } \\
27 \% \text { from } 15,000 \text { to } 28,000 \text { euros } \\
38 \% \text { from } 28,000 \text { to } 55,000 \text { euros } \\
41 \% \text { from } 55,000 \text { to } 75,000 \text { euros } \\
43 \% \text { over } 75,000 \text { euros }\end{array}$ & $\begin{array}{l}0 \% \text { from } 0 \text { to } 9,700 \text { euros } \\
14 \% \text { from } 9,701 \text { to } 26,791 \text { euros } \\
30 \% \text { from } 26,792 \text { to } 71,826 \text { euros } \\
41 \% \text { from } 71,827 \text { to } 152,108 \text { euros } \\
45 \% \text { over } 152,108 \text { euros }\end{array}$ \\
\hline Tax credits & $\begin{array}{l}\text { Tax credits for income source } \\
\text { Tax credits for household dependents } \\
\text { (spouse, children and other household } \\
\text { members) } \\
\text { Other minor tax credits }\end{array}$ & $\begin{array}{l}\text { Tax relief (Décote) and other minor tax } \\
\text { credits }\end{array}$ \\
\hline Net tax & $y \times$ rate - tax credits & $\operatorname{Max}\left\{\frac{y}{q} \times\right.$ rate $\left.\times q ; I_{q}^{M A X}\right\}-$ tax credits \\
\hline
\end{tabular}

‡For details, see appendix 1. 


\subsection{Cash subsidies to households with children}

The system of cash subsidies to households is much more generous and developed in France than in Italy. In Italy, the subsidies are the following::

- Family allowances (AF). These are the most important subsidies to households with children. The recipients are households whose total income is composed of at least $70 \%$ of income deriving from employment, pension, unemployment or ordinary layoff funds. The amount of the allowance depends on the type of household unit (single parent or with both parents) and whether there are children under 18; it goes up by number of members and goes down, to zero, by total family income classes.

- Baby bonus (BB). Introduced in 2015, this is a subsidy of 960 euros per year for children born or adopted that is paid up to the age of three to households whose Equivalent Economic Situation Indicator (ISEE) iii is lower than 25,000 euros. The subsidy is increased to 1,920 euro per year for households whose ISEE is lower than 7,000 euros.

- Birth Bonus (PN). 800-euro lump-sum subsidy paid to any household for the birth or adoption of a child.

- Family allowances for households with three children (AF3). Households whose ISEE is lower than 8,556 euros receive 141.3 euros on a monthly basis. Since 2016, households with at least four children have received an additional 500 euros per year.

In France, the system of cash subsidies to households is composed of the following measures: ${ }^{\text {iv }}$

- Family Allocation (AF). This benefit is paid to households with at least two dependent children. Children are considered dependent persons if they are aged under 20 and earn less than 55\% of the minimum wage. The benefit became means-tested starting in 2015 for families who earned more than a defined threshold. The theoretical benefit amount depends on the number and age of dependent children: for example, a household with two children receives 130 euros a month, and one with three children receives 297 euros. Each child after the 3rd receives an additional amount of 167 euros a month. Further combinations relating to age and number of children and income yield different monthly amounts.

- Early Childhood Home Benefit (PAJE). The benefit is received by households with children under 3. Entitlement to the PAJE base amount is subjected to an income test. The theoretical monthly amount per family is 185 euros. A percentage is applied to this value according to household income, number of working parents and number of children. 
- Birth Bonus (PN). A 927-euro lump-sum subsidy paid to households for the birth of a child, increased to 1,855 euros for children who are adopted. Like all the others, this measure is household income based, with thresholds depending on the number of earners and children.

- Back to school allocation (ARS). This subsidy goes to households with children attending school between the ages of 6 and 18. It amounts to 366 euros for children between the ages of 6 and 10, 386 euros for children between the ages of 11 and 14 and 399 euros for children between the ages of 15 and 18. This measure involves a means test by income and number of children.

- Family support allowance (ASF). This is additional support for children who have only one parent or who live with their grandparents. It does not depend on household income, and it amounts to 110 euros per month if the child has only one parent and 147 euros if the child lives with his or her grandparents.

- Family supplement $(C F)$. This is yet another benefit for households with at least three children, all of them older than three. The theoretical benefit remains the same regardless of the number of children, while the effective benefit depends on household income. The subsidy is equal to 170 euros per month for a household with one income earner and income lower than 37,705 euros or two income earners and income lower than 46,125 euros. Additionally, the benefit amount is increased for households with lower income.

\section{THE DISTRIBUTIVE EFFECTS OF A SHIFT TO THE FRENCH INCOME TAX}

In this section, we assess the distributive effects of the shift from the Italian tax and benefit system to the French one. In addition, we estimate the possible disincentive effect on female labor supply that could result from this income tax reform. We use MicroReg, a fiscal microsimulation model built on the Italian subsample of the EUSILC (Maitino et al., 2017), which simulates the first-order effects of hypothetical tax and benefit reforms in Italy. ${ }^{\mathrm{V}}$

\subsection{From Italy's IRPEF to the French income tax}

In this section, we evaluate the effects of a shift from the IRPEF to the French income tax system through a static simulation exercise. Similar exercises were performed for other countries in Steiner and Wrohlich (2006) and Ghysels et al. (2011). Steiner and Wrohlich (2006) analyze the effects of three different proposals to introduce a family tax splitting system in Germany. Ghysels et al. (2011) simulate and evaluate the effects of abolishing the Belgian "marital quotient" and tax deduction for childcare and the contemporaneous introduction of a new parental subsidy. 
For Italy, Cavallini and Fiorio (2006) simulate only a partial application of the French income tax, regarding the fiscal definition of the family, the family quotient and the tax bracket structure; they leave in place Italian tax credits, except tax credits for family burdens.

In what follows, we simulate a complete shift to the French income tax system, ensuring financial neutrality. In contrast to the above-mentioned literature, the French fiscal rules are fully applied to Italy, except for a reformulation of income brackets needed to maintain the same tax revenue.

\subsubsection{Distributive effects}

We estimate the average change in the tax burden aggregating families in deciles of their equivalent gross income. Figure 1 shows both the change in the tax actually paid and the change in the tax rate. After the reform, the change in the average tax paid is negative up to the fourth decile, reaching its maximum in the third decile with an annual value of -135 euros (Figure 1(a)). It becomes positive starting from the fifth decile until it reaches the highest value of 600 euros in the last. The change in tax incidence in relation to income is negative but limited (-0.4-0.5\%) in the initial deciles, taxed near zero in both systems (Figure 1(b)). It reaches the maximum reduction in the third decile ($0.8 \%$ ) for incomes still taxed near zero in the French system. The tax incidence of the French system exceeds that of the Italian system starting from the fifth decile of the income distribution, reaching its maximum value in the last decile $(0.6 \%)$. The incidence curves in Figure 1 clarify that, although limited and not strictly monotonic - the most advantaged group is the third decile - the effect of the application of the French system to Italy is progressive, on average. 
Figure 1 Distributive effects by deciles of equivalent gross household income

(a) Tax difference (post - pre-reform)

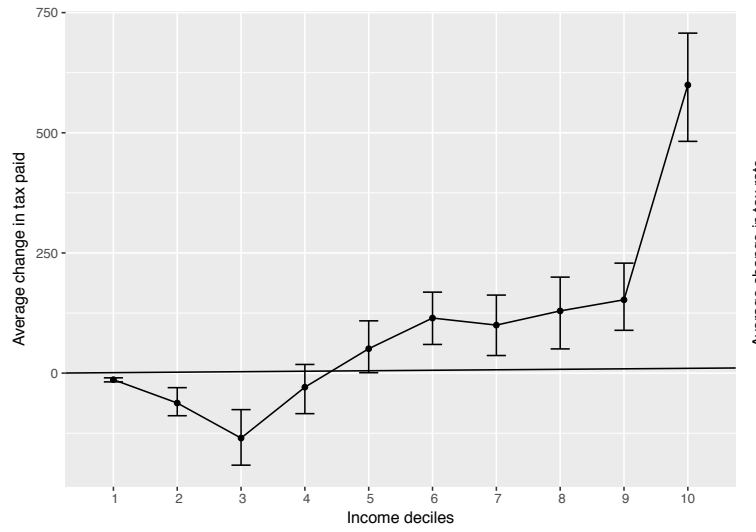

(a) Tax difference (post - pre-reform)

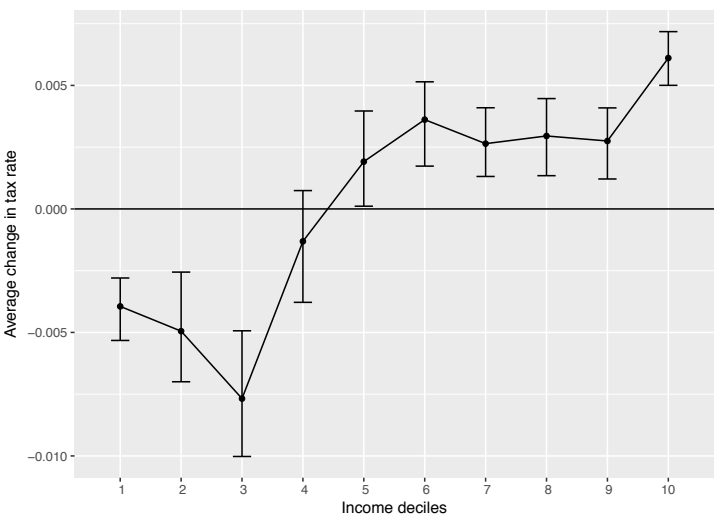

Source: MicroReg based on EUSILC, 2016 (2016). 95\% confidence intervals obtained with 200 bootstrap resamples.

To evaluate the possible reform in terms of horizontal equity, we repeat the exercise, distinguishing households by the presence of children and keeping in mind that households without children represent $70 \%$ of the total in Italy. Families without children suffer an increase in the tax burden, while those with children enjoy a greater reduction with each additional child (Figure 2(a)).

For households with children, the tax paid begins to shrink to a great extent from the third decile (Figure 2(b)). In the subsequent deciles, the tax variation for households with one or two children is similar. After having reached its maximum value in the third decile, the tax benefit tends to be reduced as income increases, particularly for one-child households. Nonetheless, we notice discontinuities in the sixth and seventh deciles for households with one and two children that depend on the zeroing of Italian tax credits, which makes the French system convenient more generous again, up until the higher rates.

Figure 2 Distributive effects by number of children and deciles of equivalent gross household income
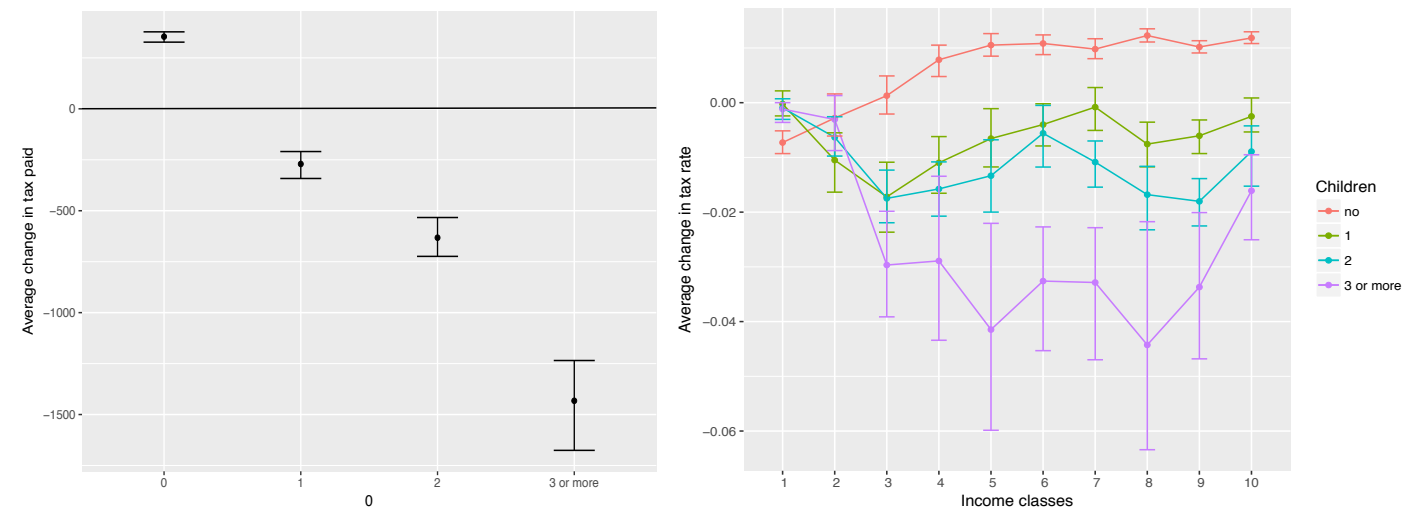

Source: MicroReg based on EUSILC, 2016 (2016). Confidence intervals obtained with 200 bootstrap resamples. 
The real winners in the transition from the Italian to the French system are households with three children. For them, tax relief increases with income level, reaching a maximum reduction of $5 \%$ in the ninth decile and decreasing only in the highest decile. ${ }^{\text {vi }}$ The tax relief that households with children would enjoy is clearly paid by the richest $70 \%$ of the households that do not have children.

\subsubsection{Disincentive to female labor supply}

The introduction of joint taxation on total household income is typically considered a possible disincentive to the labor supply from the household member that has the lower salary, which in the Italian context is typically a woman. In the case of separate taxation, the spouse whose income is lower is faced with a relatively low marginal tax rate, regardless of the income of the other household earner. ${ }^{\text {vii }}$ Conversely, joint taxation provides an identical marginal rate for both spouses, which depends on the sum of their incomes. This means that even someone with a very low salary, such as an unemployed mother without any specific job qualifications, may have to face a high marginal tax rate. Since net wages determine the decision to supply labor, joint taxation has the effect of incentivizing specialization, all the more so when there are dependents; the spouse whose salary is higher will maximize work hours, while the spouse whose salary is lower will minimize labor supply and specialize in taking care of the household. This is a negative effect when one considers the female labor participation targets in the European Union, of which Italy still falls very short, especially in its Southern area (Eurostat, 2018). We therefore calculated how the "marginal" tax rate would change for nonworking women after the French system is introduced. Of course, the change in paid tax depends on the yearly salary the worker will earn once she enters the labor market. To obtain an idea of the magnitude of the possible disincentive, in Table 4, we provide an example by calculating for the two systems the tax rate paid by women who do not work if they start working part-time and receive a gross salary of 12,000 euro a year. This is repeated for each decile of the gross family income distribution. Table 4 shows the presence of a strong disincentive effect: in the aggregate (last line in the table) $85 \%$ of nonworking women would pay a higher rate under the reformed system, increasing from an average of $11 \%$ to $23 \%$. However, this effect varies greatly depending on the household income level. For lower-income households in the first decile, the effect goes the other way; only 95\% of them would pay according to a lower rate $(1 \%$ versus $6 \%$ in the current system). The above results from the interaction between joint taxation and the greater progressivity of the French system allows us to exclude a strong disincentive effect on the female labor supply, at least for households that are less well off. 
Table 4: Average rate paid on 12,000 euros of additional income for nonworking Italian women by income deciles

\begin{tabular}{|c|c|c|c|c|c|c|c|c|c|c|c|c|}
\hline \multirow[t]{2}{*}{ Deciles } & \multicolumn{3}{|c|}{$\begin{array}{c}\text { Pre reform } \\
\text { Marginale tax rate }\end{array}$} & \multicolumn{3}{|c|}{$\begin{array}{c}\text { Post reform } \\
\text { marginale tax rate }\end{array}$} & \multicolumn{3}{|c|}{$\begin{array}{l}\text { Diff. between post } \\
\text { and pre reform marginal rates }\end{array}$} & \multicolumn{3}{|c|}{ Share of loosers } \\
\hline & point & low & $u p$ & point & low & $u p$ & point & low & $u p$ & point & low & $u p$ \\
\hline 1 & 0.0597 & 0.0564 & 0.0628 & 0.0113 & 0.0086 & 0.0154 & -0.0483 & -0.0523 & -0.0437 & 0.055 & 0.0963 & 0.0233 \\
\hline 2 & 0.0731 & 0.0709 & 0.0766 & 0.1138 & 0.1051 & 0.1232 & 0.041 & 0.0318 & 0.0509 & 0.7359 & 0.7957 & 0.6799 \\
\hline 3 & 0.074 & 0.0712 & 0.0774 & 0.2127 & 0.2043 & 0.2223 & 0.1393 & 0.1301 & 0.1494 & 0.9403 & 0.9711 & 0.9069 \\
\hline 4 & 0.0761 & 0.0725 & 0.0799 & 0.2495 & 0.2391 & 0.2593 & 0.173 & 0.1627 & 0.1826 & 0.9237 & 0.9638 & 0.8774 \\
\hline 5 & 0.0806 & 0.0757 & 0.086 & 0.2786 & 0.2718 & 0.2825 & 0.1974 & 0.1891 & 0.2042 & 0.9586 & 0.9829 & 0.9302 \\
\hline 6 & 0.0813 & 0.0767 & 0.0871 & 0.2677 & 0.2611 & 0.2749 & 0.186 & 0.1766 & 0.195 & 0.9672 & 0.988 & 0.9404 \\
\hline 7 & 0.0875 & 0.0812 & 0.094 & 0.2659 & 0.2541 & 0.2724 & 0.1787 & 0.1655 & 0.1882 & 0.9632 & 0.9904 & 0.9202 \\
\hline 8 & 0.0934 & 0.0867 & 0.1002 & 0.2717 & 0.2697 & 0.274 & 0.1789 & 0.1725 & 0.1856 & 0.9952 & 1 & 0.989 \\
\hline 9 & 0.0981 & 0.0914 & 0.1065 & 0.2852 & 0.2793 & 0.2903 & 0.1866 & 0.1779 & 0.1949 & 0.9836 & 0.9959 & 0.968 \\
\hline 10 & 0.1156 & 0.1058 & 0.1252 & 0.3553 & 0.3496 & 0.3617 & 0.2398 & 0.2284 & 0.2505 & 1 & 1 & 1 \\
\hline Total & 0.0839 & 0.0822 & 0.0858 & 0.2311 & 0.227 & 0.2354 & 0.147 & 0.1424 & 0.1513 & 0.8519 & 0.8644 & 0.8365 \\
\hline
\end{tabular}

Source: MicroReg based on EUSILC, 2016 (2016). Confidence intervals obtained with 200 bootstrap resamples.

Note that this disincentive also depends on household structure. Depending on the number of children, a different proportion of women are not penalized by the reform if they start working for 1,000 euros a month. For $27 \%$ of women with three or more children, the marginal tax rate remains unchanged or is reduced with the reformed system (see Table B1 in Appendix B). These include $100 \%$ of the women living in low-income families (first decile) and about half of the women in the second income decile. Note that these estimates have a relatively high level of uncertainty; in the majority of the groups, the number of nonworking women is too small to calculate confidence intervals. However, point estimates suggest that the disincentive effect on labor market participation is not negligible; it is mitigated by the more progressive nature of the French tax function for households with lower taxable income, especially those that have children. These are also the households for which the political decision maker's concern is understandably greater in regard to low participation in the labor market.

\subsection{Distributive effects of French family benefits}

In France, the QF is coupled with a generous system of family benefits. A reform aimed at supporting families could also consider modifying the much less generous system of family cash transfers in place in Italy. There are many ways in which the French system of cash transfers to households could be implemented in Italy and evidently with very different distributive effects. Here, we assume the total replacement of Italian subsidies with French subsidies, even if the costs are higher (we relax the revenue invariance hypothesis assumed in the simulation of the QF) ${ }^{\text {viii }}$. In Italy, the most significant subsidy is the family allowance. Approximately 3.8 million households with children benefit from an average amount of 1,248 euros per year (see Table B3 in Appendix). There are fewer recipients of baby bonuses and birth bonuses. The allowance for households with 
three minor children also concerns a low number of households both because there are few households with three children and because of the restrictive selection criteria.

If the French measures were applied to Italy, the recipients of some transfers would increase by $30 \%$, affecting approximately 1.3 million additional households. The average amount disbursed would be almost twice the current amount, 2,606 versus 1,478 euros (Table B4 in Appendix). However, single-child households on average would not be benefited by transitioning to the French system. For them, the average disbursed amount would remain practically constant, and the number of households benefiting from at least one subsidy would decrease. In fact, households with one dependent child currently receive family allowances in Italy, while France's Allocation Familiale grants a subsidy only to households with at least two children and additional benefits to even larger households. The total expenditure for the benefit of households with one child would be even lower with the French system (see Table B5 in Appendix).

Households with at least two children would face different effects. Thanks to the set of subsidies provided in France, the average amount of benefits increases among households with two children. For households with three children, the increase in the average amount paid is even more significant. Figure 3(a) shows the difference in cash transfers received by Italian families after the reforms.

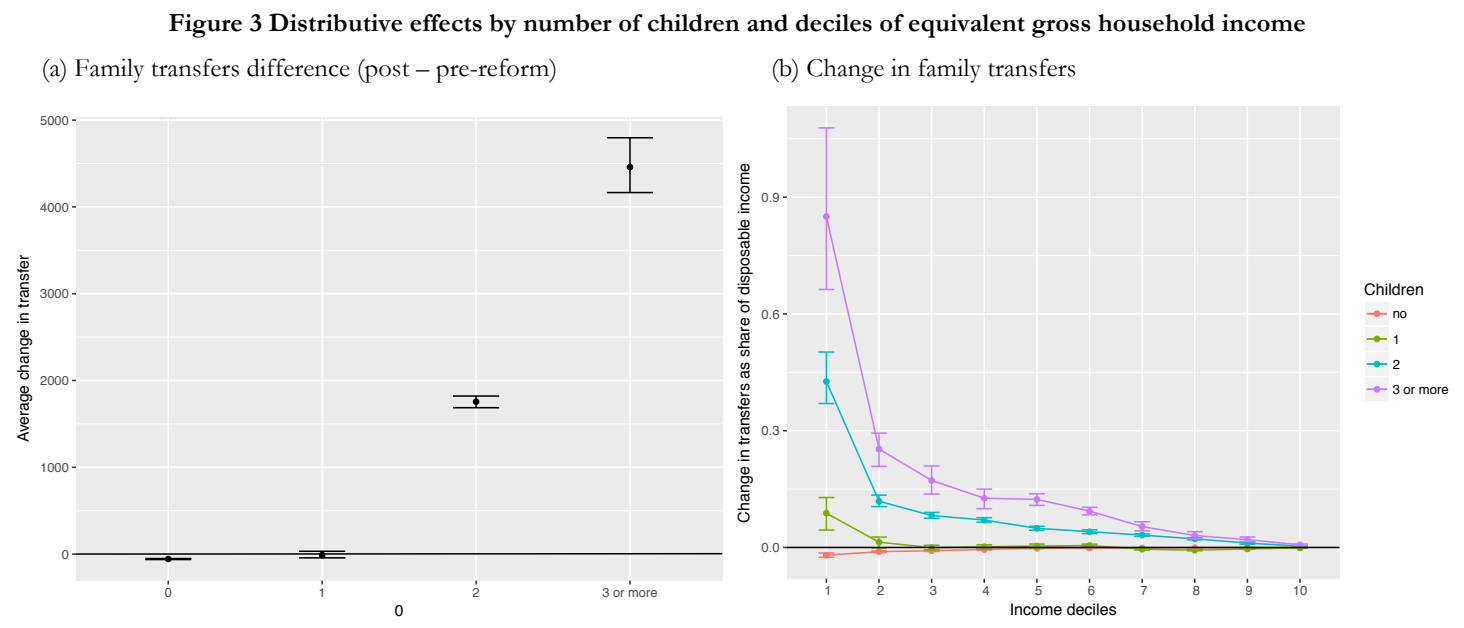

Source: MicroReg based on EUSILC, 2016 (2016). Confidence intervals obtained with 200 bootstrap resamples.

Furthermore, except for the allowances for households with three minor children, Italian subsidies have limited distributive efficacy (see Table B5 in Appendix). In total, 73\%, 52\% and $72 \%$ of households belong to the first five deciles of the income distribution, respectively, for the baby bonus, birth bonus and family allowances. However, the share of expenditure allocated to higher deciles of income, from the sixth to the eighth, is not negligible. Only the last two deciles are 
practically excluded from the measures. French transfers have similar distributions, with the only exceptions of the Complément familial and the Allocation de rentrée scolaire, which are more pro-poor than those in Italy and more similar to the Italian allowance for households with three minor children. As shown in Figure 3 (b), where the change in transfers is disaggregated by income decile, overall, French subsidies turn out to be more pro-poor than Italian subsidies.

Inequality and progressivity indicators confirm the findings in the preceding sections. The degree of progressiveness of the tax inspired by French taxation is higher than that of the IRPEF even when considering the differences between the two populations in terms of demographic structure (fewer children in Italy) and income distribution (lower average income). Therefore, after taxes, equivalent income inequality is more reduced in the reformed system than in the current system. The French cash family benefits are also more progressive than the Italian ones. The greater reduction in inequality of equivalent incomes after subsidies in the French system depends on the utilization of greater resources in addition to higher progressiveness. A total shift from the Italian tax and benefit system to the French tax would reduce the inequality of the equivalent gross income distribution. The Gini index after taxes and subsidies is in fact equal to 0.2947 in the Italian system and 0.2854 in the French system.

Table 5: Indices of inequality of the equivalent gross household income

\begin{tabular}{|c|c|c|c|c|c|c|}
\hline & Pre reform & & & After reforr & & \\
\hline & point & low & $u p$ & point & low & $u p$ \\
\hline Gross income (Gini) & 0.3977 & 0.3918 & 0.4038 & & & \\
\hline Gross income - tax (Gini) & 0.3515 & 0.3457 & 0.3565 & 0.3493 & 0.3442 & 0.3551 \\
\hline Tax-Kakwani & 0.1883 & 0.1856 & 0.1911 & 0.1899 & 0.1866 & 0.1931 \\
\hline Transfer-Kakwani & -0.5041 & -0.5193 & -0.487 & -0.5563 & -0.5796 & -0.5385 \\
\hline Disposable income & 0.3469 & 0.3421 & 0.352 & 0.3402 & 0.3354 & 0.3445 \\
\hline
\end{tabular}

\section{CONCLUSION}

A reform of the Italian tax system inspired by the French model has on several occasions been evoked in the Italian public debate with the aim of increasing our country's birth rate. The French tax and benefit system is, among European countries, one of the most generous to large families. The empirical literature has shown that fiscal policies affect birth rates, albeit moderately, and a few contributions have shown that the French fiscal system may explain a nonnegligible part of the (relatively high) fertility rate. However, in addition to stimulating births, such a reform of the 
Italian fiscal system would have other effects; this paper has focused on the consequences that it would have on the horizontal and vertical equity guaranteed by the current tax system.

For income taxes, according to our analysis, a shift to the French income tax system would increase progressivity and benefit households with at least three children. The benefit for the other households with children would be smaller. This evidence deserves reflection, as the French system seems to be set up to encourage having three children rather than two; the French system's effectiveness in terms of birth rate could therefore be linked to the fact that many households are undecided between having two or three children. The percentage of the similarly undecided households is probably much lower in Italy.

Furthermore, introducing a household income tax inspired by the French model in Italy would produce a series of additional relevant effects. A substantial disincentive to female labor supply would arise. Such an effect is mitigated by greater progressivity for low-income groups and in the presence of children, but a simple simulation exercise estimates that over $70 \%$ of nonworking Italian women would see their marginal tax rate grow and therefore would find it less convenient to get a job or start a business.

Moreover, if the reform would concern both the tax and benefit, one has to consider that the generous French system of transfers for households with children would obviously be much more expensive than the current one, so there would be a problem of resources. Assuming financial coverage, the French subsidy system would undoubtedly be more progressive than the Italian system, with a greater concentration of resources in the poorer sections of the population. However, only households with at least two children would benefit from the reform, while those with only one child would even suffer a slight setback, with fewer subsidy beneficiaries and lower overall expenditure. Again, the great advantage of having three children instead of two may deserve careful consideration in a country where the share of families with three children is less than $5 \%$. Applying the French system in Italy is possible, but its effects depend crucially on how the Italian system would be modified, for example, whether we would want to adopt only the quotient system or also replicate the tax rates or the whole French system, including the cash subsidies to households. The French system pays more attention to household responsibilities. However, these can only be replicated with great budget resources.

What does the French tax-benefits system teach us? First, it is necessary to allocate more resources than those currently assigned to families with children. Second, each tax-benefit system is closely connected to the characteristics of the country in which it is applied, and the mere transposition of a system in another country does not necessarily produce the desired effects. 


\section{REFERENCES}

Breton D. e Prioux F. (2005), “Deux ou trois enfants ?”, Population 2005/4 (Vol. 60), p. 415-45.

Cavalli M. and Fiorio C. (2006), "Individual vs family taxation: an analysis using TABEITA04", Econpubblica WP, No. 118, Bocconi University, Milan, December.

De Nicola F. (2009), “Tassazione e Sostegno del Reddito Familiare”, ISAE, Working paper n. 118, September 2009.

Ekert-Jaffé O. (1986), "Effets et limites des aides financières aux familles: une expérience et un modèle", Population (french edition), 327-348.

Eurostat (2018) "Employment rates and Europe 2020 national targets".

Gauthier H. (2007), “The impact of family policies on fertility in industrialized countries: a review of the literature.", Population research and policy review 26.3 (2007): 323-346.

Ghysels, J., Vanhille J. and Verbist, G. (2011), “A care time benefit as a timely alternative for the non-working spouse compensation in the Belgian tax system", International Journal of Microsimulation, 4(2), 57-72.

Landais C. (2004), “Le quotient familial a-t-il stimulé la natalité française?”, Économie publique/Public economics, (13).

Laroque G. e Salaniè B. (2014), "Identifying the response of fertility to financial incentives.", Journal of Applied Econometrics 29.2 (2014): 314-332.

Maitino M.L., Ravagli L. e Sciclone N. (2017), "MicroReg based on EUSILC, 2016: A Traditional Tax-Benefit Microsimulation Model Extended To Indirect Taxes And In Kind Transfers", International Journal of Microsimulation, 10(1), 5-38.

Piketty T. (2005), “Impact de l'Allocation parentale d'éducation sur l'activité féminine et la fécondité en France", Histoires de familles, histoires familiales, 156, 79-109.

Rapallini C. (2006), “Il quoziente familiare: valutazione di un'ipotesi di riforma dell'imposta sul reddito delle persone fisiche (No. 475)", working paper.

Sleebos J. (2003), “Low Fertility Rates in OECD Countries: Facts and Policy Responses”, OECD 
Labour Market and Social Policy Occasional Papers, No. 15, OECD Publishing, Paris.

Steiner V. and Wrohlich K. (2008), "Introducing family tax splitting in Germany: How would it affect the income distribution, work incentives, and household welfare?", FinanzArchiv: Public Finance Analysis, 64(1), 115-142.

Thevenon O. (2009), "Does fertility respond to work and family reconciliation policies in France?", Fertility and public policy: How to reverse the trend of declining birth rates.

Thévenon O. e Gauthier A. (2011), “Family policies in developed countries: A 'fertility-booster' with side-effects." Community, Work \& Family 14.2 (2011): 197-216. 


\section{APPENDIX A : PLAFONNEMENT DU QUOTIENT FAMILIAL}

The tax payable by the household unit is calculated as the maximum between two amounts: the tax that the household should pay considering the income divided by the quotient, $\mathrm{T}_{\mathrm{F}}$, and the tax that the household should pay with the maximum tax advantage obtained through the presence of children, $I_{M A X}$.

$\mathrm{T}_{\mathrm{F}}$ is obtained in the following way:

- the quotient is calculated as the sum of the "parts" (q)

- the household taxable income is divided by the quotient: $Y=y / q$

- the tax per "part" is calculated by applying to the taxable income per "part" the legal tax rate of the corresponding bracket: $\tau=Y \times t$

- the tax is obtained by multiplying the tax per "part" by the quotient $T_{F}=\tau \times Q$

$I_{M A X}$ is the tax payable by a household consisting of spouses (or a single person) under the assumption of no children, $\mathrm{T}_{\mathrm{NF}}$, minus the maximum ceiling to the tax advantage obtained through the presence of children (ceiling) $\left(\mathrm{T}_{\mathrm{NF}}-\right.$ ceiling $)$.

$\mathrm{T}_{\mathrm{NF}}$ is obtained in the following way:

- the income is divided by the quotient net of children $(q=2$ for spouses, $q=1$ for a single person)

- the tax per "part" is calculated as $\tau=y \times \mathrm{t}$

- $\mathrm{T}_{\mathrm{NF}}$ is the product of the tax per "part" and the quotient $(\tau \times Q)$.

The ceiling to the tax advantage obtainable thanks to the presence of children is equal to the following:

- 3,562 euros for each of the first two 0.5 "parts" in the case of a single parent;

- 1,510 euros for each of the 0.5 additional "parts" to the first two in the case of a single parent;

- $\quad 1,510$ euros for each of the 0 .5 "parts" in the case of a couple. 


\section{APPENDIX B: ADDITIONAL TABLES}

Table B1: Percentage of non-working women who pay a higher rate on 12,000 euros of additional income by deciles of income and number of children

\begin{tabular}{|c|c|c|c|c|}
\hline Gross income deciles & Without children & 1 child & 2 children & $3+$ children \\
\hline 1 & 0.07 & 0.02 & 0.07 & 0.00 \\
\hline 2 & 0.74 & 0.84 & 0.75 & 0.52 \\
\hline 4 & 0.91 & 0.94 & 0.99 & 1.00 \\
\hline 5 & 0.95 & 1.00 & 1.00 & 1.00 \\
\hline 6 & 0.95 & 1.00 & 1.00 & 1.00 \\
\hline 8 & 0.99 & 1.00 & 1.00 & 1.00 \\
\hline 9 & 0.98 & 1.00 & 1.00 & 1.00 \\
\hline 10 & 1.00 & 1.00 & 1.00 & 1.00 \\
\hline Total & 0.87 & 0.85 & 0.84 & 0.73 \\
\hline
\end{tabular}

Table B2: Italian subsidies by benefit average amount and number of $\mathrm{HH}$ recipients

\begin{tabular}{|c|c|c|c|c|c|}
\hline & & 1 & 2 & $3+$ & Total \\
\hline \multirow[t]{2}{*}{ Baby bonus } & Amount (euro) & 1,117 & 1,397 & 1,422 & 1,281 \\
\hline & Recipients (thousand) & 165 & 168 & 54 & 388 \\
\hline \multirow[t]{2}{*}{ Birth bonus } & Amount (euro) & 800 & 834 & 825 & 817 \\
\hline & Recipients (thousand) & 225 & 203 & 57 & 485 \\
\hline \multirow[t]{2}{*}{ Family allowance } & Amount (euro) & 800 & 1,369 & 2,614 & 1,248 \\
\hline & Recipients (thousand) & 1,748 & 1,706 & 423 & 3,878 \\
\hline \multirow{2}{*}{$\begin{array}{l}\text { Municipal family allowances for } \\
\text { households with three children }\end{array}$} & Amount (euro) & & & 1,696 & 1,696 \\
\hline & Recipients (thousand) & & & 316 & 316 \\
\hline \multirow[t]{2}{*}{ Total } & Amount (euro) & 926 & 1,523 & 3,274 & 1,478 \\
\hline & Recipients (thousand) & 1,903 & 1,799 & 539 & 4,242 \\
\hline
\end{tabular}

Source: MicroReg based on EUSILC, 2016 (2016)

Table B3: French subsidies by benefit average amount and number of $\mathrm{HH}$ recipients

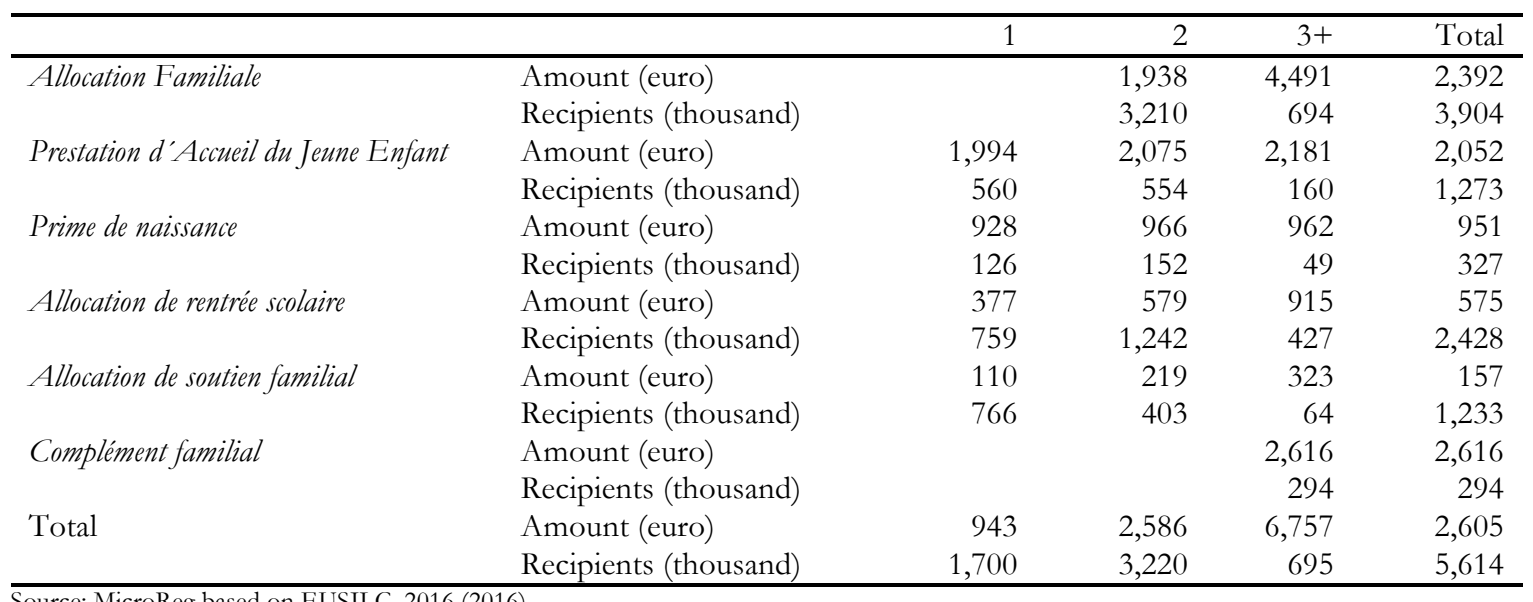


Table B4: Total expenditure by number of children

\begin{tabular}{lcc}
\hline & $\begin{array}{c}\text { Pre reform } \\
\text { transfers (mln euros) }\end{array}$ & $\begin{array}{c}\text { Post reform } \\
\text { transfers (mln euros) }\end{array}$ \\
\hline 1 child & 1,764 & 1,603 \\
2 children & 2,741 & 8,327 \\
$3+$ children & 1,767 & 4,693 \\
Total & 6,271 & 14,623 \\
\hline Source: MicroReg based on EUSILC, 2016 (2016)
\end{tabular}

Source: MicroReg based on EUSILC, 2016 (2016)

Table B5: Percentage distribution of subsidies by deciles of equivalent gross household income

\begin{tabular}{|c|c|c|c|c|c|c|c|c|c|c|c|c|}
\hline \multirow[b]{2}{*}{ Decile } & \multicolumn{7}{|c|}{ Post reform } & \multicolumn{5}{|c|}{ Pre reform } \\
\hline & $\mathrm{AF}$ & PAJE & $\mathrm{PN}$ & ARS & $\mathrm{ASF}$ & $\mathrm{CF}$ & Total & $\mathrm{BB}$ & $\mathrm{PN}$ & $\mathrm{AF}$ & AF3 & Total \\
\hline 1 & 0.18 & 0.17 & 0.13 & 0.30 & 0.24 & 0.31 & 0.19 & 0.17 & 0.09 & 0.11 & 0.45 & 0.15 \\
\hline 3 & 0.12 & 0.14 & 0.10 & 0.23 & 0.11 & 0.13 & 0.14 & 0.09 & 0.07 & 0.17 & 0.09 & 0.15 \\
\hline 4 & 0.10 & 0.16 & 0.18 & 0.11 & 0.13 & 0.07 & 0.11 & 0.12 & 0.13 & 0.13 & 0.00 & 0.12 \\
\hline 5 & 0.09 & 0.13 & 0.10 & 0.02 & 0.08 & 0.05 & 0.09 & 0.07 & 0.07 & 0.09 & 0.00 & 0.08 \\
\hline 7 & 0.09 & 0.06 & 0.10 & 0.00 & 0.06 & 0.00 & 0.07 & 0.08 & 0.09 & 0.09 & 0.00 & 0.08 \\
\hline 8 & 0.06 & 0.01 & 0.01 & 0.00 & 0.04 & 0.00 & 0.04 & 0.08 & 0.13 & 0.06 & 0.00 & 0.06 \\
\hline 9 & 0.04 & 0.00 & 0.00 & 0.00 & 0.07 & 0.00 & 0.02 & 0.01 & 0.08 & 0.04 & 0.00 & 0.03 \\
\hline 10 & 0.02 & 0.00 & 0.01 & 0.00 & 0.04 & 0.00 & 0.01 & 0.00 & 0.06 & 0.02 & 0.00 & 0.02 \\
\hline Total & 1.00 & 1.00 & 1.00 & 1.00 & 1.00 & 1.00 & 1.00 & 1.00 & 1.00 & 1.00 & 1.00 & 1.00 \\
\hline
\end{tabular}

i Later replaced by the current Prestation d'Accueil du Jeune Enfant (PAJE).

iiRegional subsidies to households with children linked to school attendance are not considered.

iiiThe ISEE (Equivalent Economic Situation Indicator) is a mean test used in Italy to determine access to and copayment in many social services. The indicator considers household income and assets jointly.

iv Only cash subsidies are considered. We chose to exclude maternity and parental leave since they depend on individual choices on returning to work after maternity and more generally on the availability of child and work care time management. The Complément de libre choix d'activité was not considered because it is similar to parental leave.

vThe tax rules considered in this paper refer to the 2016 tax returns (tax year 2015) for both Italy and France. The EUSILC sample of 2016 is used.

vi The low number of households with more than two children explains the large confidence bars for estimates of their tax change.

vii For the sake of simplicity, we exclude households with more than two income earners from this discussion.

viii Overall, the French system would be much more expensive than the one currently provided in Italy. A 8.3 billion increase would be needed. 